\title{
STUDI BISNIS PENGOLAHAN TANAMAN SAGU DI KABUPATEN DESA WAELAWI MALANGKE BARAT KABUPATEN LUWU UTARA
}

\author{
Sago Plant Processing Business Studies In The District Of Waelawi Village, \\ Malangke Barat North Luwu District \\ Dharma Fidyansari $^{1)}$ Fitriyanti $^{2)}$
Email: dharmafidyansari@uncp.ac.id, fitriyantibuharni07@gmail.com
}

Program Studi Agribisnis, Universitas Cokroaminoto Palopo ${ }^{12}$

\begin{abstract}
Abstrak
Penelitian ini bertujuan untuk mengetahui teknik pengolahan tanaman sagu dan nilai pendapatan ekonomi dari pengolahan tanaman sagu di Desa Waelawi, Kecamatan Malangke Barat, Kabupaten Luwu Utara. Penelitian ini menggunakan metode deskriptif kualitatif untuk menganalisis teknik pengolahan sagu dan untuk memperoleh nilai pendapatan ekonomi untuk pengolahan tanaman sagu menggunakan analisis kuantitatif. Pengambilan sampel dikumpulkan dengan teknik total sampling dengan mengambil semua populasi yang ada (sensus). Metode wawancara gratis adalah dengan mewawancarai 10 responden yang memiliki bisnis pengolahan sagu. Hasil penelitian menunjukkan pengolahan empulur sagu menjadi pati sagu basah secara mekanis dan mekanis terintegrasi. Hasil penelitian kemudian menunjukkan 10 manajer produksi tiga kali / minggu, satu produksi dengan sepuluh batang sagu besar dapat menghasilkan sagu basah kurang dari dua ratus karung dengan berat lebih dari sepuluh ton atau produksi sagu dalam sebulan rata-rata 81,1 karung / bulan, dengan penghasilan rata-rata $\mathrm{Rp}$ 9.756.000,-/bulan.
\end{abstract}

Kata kunci: Sagu, Pengolahan, Waelawi, Malangke Barat.

\begin{abstract}
This study aims to determine the technique of processing sago plants and the value of economic income from processing sago plants in Waelawi Village, West Malangke District, North Luwu Regency. This study uses descriptive qualitative methods to analyze sago processing techniques and to obtain economic income for sago processing using quantitative analysis. Sampling was collected by total sampling technique by taking all existing populations (census). The free interview method is by interviewing 10 respondents who own a sago processing business. The results showed the processing of sago pith into wet sago starch mechanically and mechanically integrated. The results of the study then showed 10 production managers three times / week, one production with ten large sago stems could produce less than two hundred sacks of wet sago weighing more than ten tons or sago production in an average of 81.1 sacks a month, with average income of IDR 9,756,000 / month.
\end{abstract}

Keywords: Sago, Processing, Waelawi, West Malangke.

\section{PENDAHULUAN}

Kabupaten di Sulawesi Selatan yang memproduksi dan mengolah sagu, yaitu Kabupaten Luwu dan Kabupaten Luwu Utara. Wilayah Kabupaten Luwu Utara, merupakan salah satu daerah dengan penyebaran sagu yang masih tersedia dalam jumlah yang cukup besar. Sejak zaman kuno, masyarakat adat telah melakukan kegiatan pengolahan sagu secara sederhana dan tradisional. 
Kabupaten Luwu Utara adalah pusat produksi sagu di Sulawesi Selatan dengan luas $1.759 \mathrm{Ha} / 1.388$ ton produksi tepung sagu. Kabupaten Luwu Utara juga merupakan salah satu kabupaten yang merupakan pusat pengembangan dan produksi sagu. Kondisi iklim dan kandungan unsur hara tanah sangat cocok untuk tanaman sagu. Di hampir setiap daerah di Kabupaten Luwu Utara ada salah satu tanaman ini di Desa Waelawi, Distrik Malangke Barat, Kabupaten Luwu Utara. Tingginya persentase orang yang sangat sering mengonsumsi sagu di Kabupaten Luwu Utara adalah karena kebanyakan orang di sekitar Luwu Utara menjadikan sagu sebagai makanan pokok kedua setelah beras. Kebiasaan mengkonsumsi sagu adalah karena rasanya yang enak dan merupakan kebiasaan turun-temurun.

Teknik pengolahan sagu yang dilakukan di Desa Waelawi selama ini menggunakan mesin sederhana sehingga hasil produksi dalam satu kali produksi tidak banyak. Kurangnya modal dalam usaha pengolahan sagu untuk mengembangkan peralatan dan membayar tenaga kerja membuat produksi mereka minim, dan terjadinya banjir yang diakibatkan hujan deras, belum lagi persoalan kurangnya air bersih ketika dalam melakukan proses pengolahan sagu, karena apabila kekurangan air dan banjir mereka tidak bisa melanjutkan pekerjaan mereka.

Kegiatan usaha pengolahan sagu terhenti apabila, terjadi banjir yang mengakibatkan berhentinya aktivitas Usaha Pengolahan Sagu dan Air yang tidak bersih atau kotor akan sangat mempengaruhi hasil akhir produksi sagu yaitu hasilnya sagu tidak berwarna putih bersih melainkan akan berwarna coklat kehitam-hitaman dan itu akan mempengarui harga sagu dan juga pasti nantinya akan mempengaruhi pendapat usaha pengolahan sagu. Perkembangan produksi usaha pengolahan sagu juga kurang diperhatikan oleh pemerintah, padahal sagu merupakan salah satu makanan pokok penganti beras sebagian masyarakat dan sebagai makanan khas Kabupaten Luwu Utara salah satunya di Desa Waelawi.

\section{METODE PENELITIAN}

Lokasi penelitian adalah Desa Waelawi, Kecamatan Malangke Barat, Kabupaten Luwu Utara. Daerah ini dipilih sebagai objek penelitian berdasarkan pertimbangannya, yaitu Desa Waelawi adalah salah satu desa di mana perkebunan sagu cukup besar dan sebagian besar penduduknya adalah produsen dan pemilik usaha pengolahan sagu. Penelitian ini 
direncanakan berlangsung selama dua bulan, mulai dari Januari 2019 hingga Maret 2019.

Analisis data yang digunakan adalah analisis deskriptif kualitatif, suatu penelitian kualitatif yang berguna untuk mengembangkan teori-teori yang telah dibangun dari data yang telah diperoleh di lapangan. Pada tahap awal, peneliti melakukan eksplorasi, kemudian melakukan pengumpulan data yang luas, mulai dari wawancara, observasi, dokumentasi. Sampel penelitian adalah seluruh populasi, yang berjumlah sepuluh orang pengusaha pengolah sagu di Desa Waelawi

\section{HASIL}

Pemrosesan empulur sagu menjadi pati sagu basah secara mekanis dan terpadu secara mekanis. Mesin yang digunakan dalam pengolahan sagu dalam mengolah batang sagu menjadi sagu basah bersifat semi-mekanis. Pengolahan sagu di Desa Waelawi, Kabupaten Luwu Utara, yaitu:

1. Langkah pertama yang diambil dalam mengolah sagu adalah pemilihan bahan baku sagu yang berumur 8 tahun karena sagu yang berumur 8 tahun memiliki lebih banyak serat sagu.
2. Setelah memilih bahan baku sagu, pemotongan pohon sagu dilakukan menggunakan mesin dan memotong pohon sagu dengan mesin, memotong pohon sagu dengan panjang satu meter.

3. Setelah memotong batang sagu, potong batang sagu di bawah ke pabrik pengolahan sagu dan kemudian mempertahankannya dengan kapak menjadi beberapa bagian untuk diparut menggunakan mesin parut semimekanis (gambar a).

4. Proses selanjutnya adalah merobekrobek batang sagu dengan jaringan parut semi-mekanis, kemudian bubur sagu disaring dengan air mengalir dari pompa yang ditarik dengan baik oleh mesin, serat sagu yang disaring disimpan selama satu hari di bak yang terbuat dari terpal yang telah dibentuk persegi panjang untuk mengakomodasi serat sagu menjadi sagu basah (gambar b \& c)

5. Setelah sedimentasi selama satu hari, proses terakhir yang dilakukan adalah pengemasan menggunakan karung berisi $50 \mathrm{~kg}$ sagu basah (gambar d). 


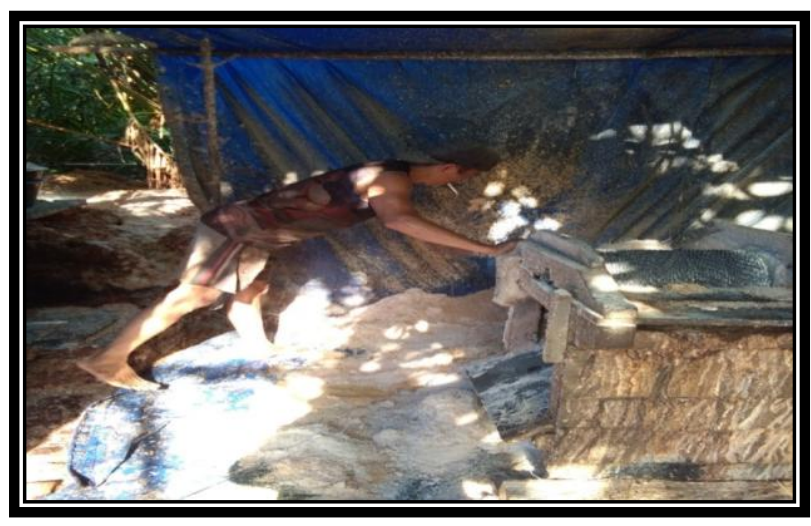

a. Sago stems extraction process

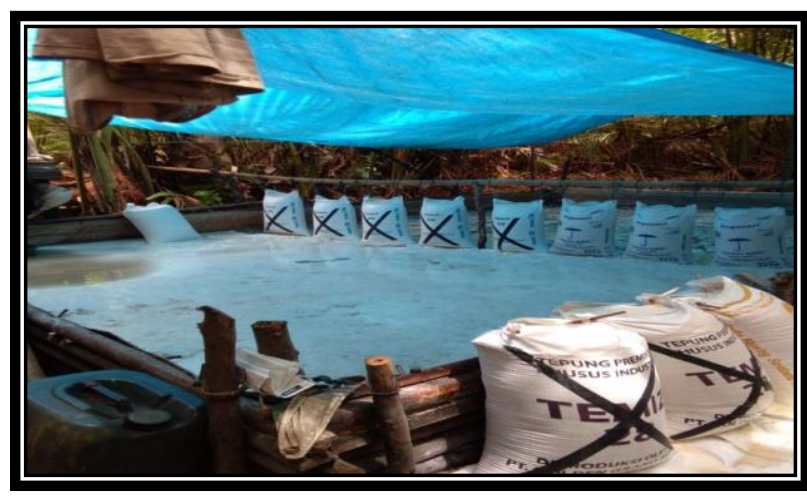

c. Sedimentation for one day

Ada sepuluh bisnis pengolahan sagu

di Desa Waelawi. Mereka melakukan kegiatan produksi tiga kali seminggu, sekali produksi dengan lima belas batang sagu biasanya menghasilkan seratus karung. Dalam proses pengolahan sagu membutuhkan dua hingga tiga orang dalam melakukan kegiatan produksi.

Proses memproduksi dan menyimpan sagu basah tidak membutuhkan waktu yang sangat lama, hal ini karena pengendapan serat sagu tidak membutuhkan waktu terlalu lama untuk menjadi sagu

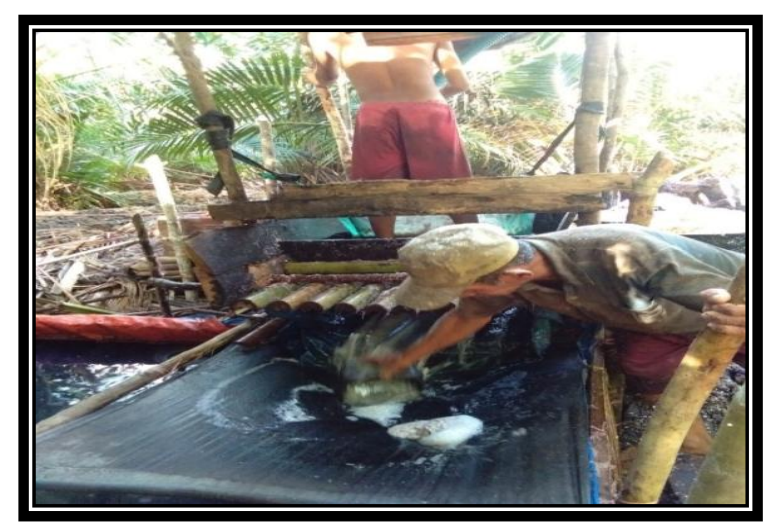

b. Sago Screening process

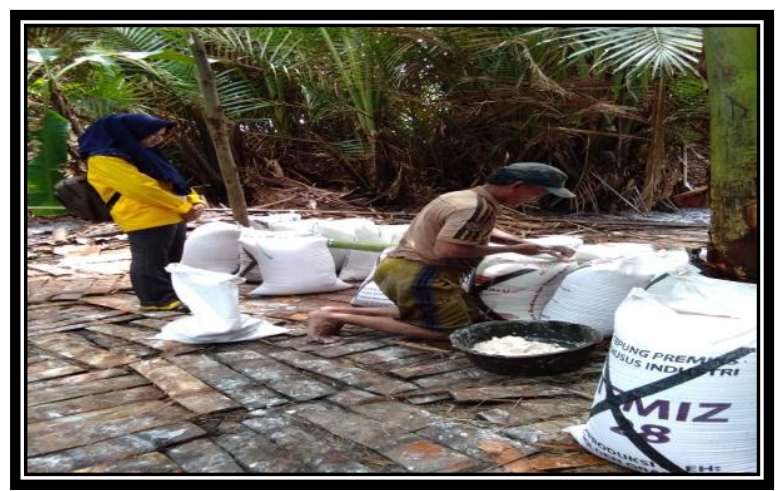

d. The Sago Processing Businesses in Waelawi

basah. Sagu yang sudah menjadi sagu basah dikemas dalam karung. Dalam memasarkan sagu basah, pemilik usaha pengolah sagu tidak menunda lama untuk memberi tahu langsung kepada konsumennya, yaitu konsumen luar dan pengumpul besar dan kecil untuk mengambil atau membeli produksi sagu basah. Ini agar distribusi produk ke berbagai daerah bisa tiba dengan cepat dan produk sagu basah tidak akan rusak di tangan konsumen.

Dalam membangun atau memulai bisnis pengolahan sagu menurut pemilik 
bisnis pengolahan sagu ada beberapa peralatan yang harus dibutuhkan seperti shredder, mesin senso, pompa air, kapak, parang, dan terpal. Total modal peralatan adalah sekitar Rp7.000.000. Modal awal yang dibutuhkan dalam mendirikan bisnis tidak terlalu besar. Berdasarkan hasil penelitian terhadap 10 bisnis pengolahan sagu, berikut ini diketahui: (1). Rata-rata Hasil Sagu Basah per Tahun adalah 81,1 karung / tahun; (2) Pendapatan rata-rata adalah Rp117.012.000 / tahun atau Rp9.756.000, - dengan harga rata-rata sagu yaitu Rp120.000 .- / karung.

\section{Kesimpulan}

Teknik pengolahan sagu di Desa Waelawi bersifat semi modern, proses pemotongan batang sagu masih tradisional, sehingga pengolahan sagu masih lambat. Namun, mesin yang digunakan dalam pengolahan sagu dalam mengolah batang sagu menjadi sagu basah bersifat semimekanis. Mengamati modal awal dan penghasilan per bulan dalam menjalankan bisnis ini dapat disimpulkan bahwa bisnis ini sangat layak untuk dijalankan. Dalam penelitian ini, studi kelayakan pengolahan sagu belum dilakukan. Untuk penelitian selanjutnya akan melihat kelayakan usaha pengolahan sagu.

\section{DAFTAR PUSTAKA}

Haryanto, B dan Pangloli. 1992. Potensi dan Pemanfaatan Sagu. Yogyakarta: Kanisius.

Timisela, N.R. 2006. Analisis usaha sagu rumahtangga dan pemasarannya. Agroforestri. Fakultas Pertanian Unpatti Ambon, 1 (3), 57-64.

Tirta, P.W.W.K., N. Indrianti, dan R. Ekafitri. 2013. Potensi tanaman sagu (Metroxylon sp.) dalam mendukung ketahanan pangan di Indonesia. Pangan, 22 (1), 61-78.

Tim Penyusun RPJMDes. 2016. RPJMDes 2016-2022 Desa Waelawi Malangke Barat Luwu Utara. 